\title{
Intranet and Knowledge Management: Putting the cart before the horse?
}

Authors:

1) Satrijo Tanudjojo

Executive Doctorate Programme, Cranfield School of Management, satrijo.tanudjojo.dba.02@ cranfield.ac.uk

2) Ashley Braganza

Centre for the Management of Organisational Transformation, Cranfield School of Management, a.braganza@ cranfield.ac.uk

Key words: Information Technology, Intranet, Internet, Knowledge Management, Knowledge Strategy 


\title{
Intranet and Knowledge Management: Putting the cart before the horse?
}

\begin{abstract}
This paper explores the use of intranet-technology to support knowledge intensive decisionmaking in a technical service delivery process of a major oilfield services company. Our findings show that creating, mobilizing, and exchanging knowledge through an intranet-technology based system delivers forms of benefits to both the organization and its clients, and understanding what organizational knowledge is to be managed and the process of managing it define the role of technology that enables knowledge management.
\end{abstract}

\section{Introduction}

We know that business is conducted increasingly in environments characterized by knowledge intensity (Davenport et al, 2003; Buckley and Carter, 2000), that availability of Information Technology (IT) enables knowledge capture and exchange to an extent unimaginable a decade ago (Davenport and Prusak, 1998). However, for many organizations, knowledge management benefits, accruing from the use of IT, remain elusive (Davenport et al, 1998; Earl and Scott, 1999). Hansen et al (2001; 1999) and Davenport $(1998 ; 1994)$ suggest managers believe that once the right technology is in place, knowledge management follows. They further argue that while technology is important to managing knowledge, organizations must begin with how people use knowledge, not how people use machines. While we agree with their argument, details of how companies use technology for knowledge capture and exchange and how this technology is implemented in a global company to support appropriate decisions and actions remain sketchy. Lack of clarity and the over-promising of benefits risks knowledge management becoming hype (Blair, 2002; Braganza and Möllenkramer, 2002; Southon et al, 2002). 
In this paper, we examine the use of an intranet-technology based system in relation to knowledge interaction, and its use to support intensive knowledge activities between different communities of practice (Kogut, 2000; Wenger, 2000). We conducted an indepth study in an oilfield services company, Gamma International, using a qualitative research design to understand how members of individual communities - using intranettechnology - create, mobilize, and exchange knowledge.

The paper proceeds as follows: Following this introduction is a review and discussion of relevant concepts in the literature. Then, we explain the study methods, the basis for selecting the case study setting and data collection and analysis techniques used. The findings from the case study, Gamma International, is presented next. We develop key lessons for the implementation of knowledge management that produce beneficial results, with links to literature to contribute to the academic debate. The paper closes with a brief summary.

\section{Theoretical background}

Grant (1996) and Kogut and Zander (1992) suggest a knowledge-based view of the firm. This view contends that knowledge is created, mobilized, and exchanged in social communities, e.g. organizations. Drucker argues that "the performance of an individual, an organization, an industry, a country, in acquiring and applying knowledge will increasingly become the key competitive factor" (1995:236). Therefore, conventional economic resources such as land and capital play a lesser role in an organization's quest to sustain competitive advantage as compared with its capability to exploit knowledge 
(Kogut and Zander, 1992; Barney, 1991). Kogut and Zander further suggest that if organizational knowledge is understood as socially constructed, the knowledge that enables competitive advantage must be a combination of tacit and explicit knowledge.

Knowledge management emerged in early 1990s following the widespread use of IT. Many scholars argue that knowledge management requires IT to be effective (Birkinshaw and Sheehan, 2002; Davenport and Prusak, 1998). The development of IT for knowledge management, or Knowledge Management System (KMS) involves its use to facilitate social network interaction as well as content management. The recent development of KMS further includes the integration of different knowledge management initiatives within an organisation and between different organisations (for example Francis and Bessant, 2005; Cummings, 2004; Grant and Baden-Fuller, 2004). The KMSs supporting this generation may be tools such as Integrated Enterprise Applications. The objective is to optimise the different combinations of existing knowledge management systems for the improved performance of certain alliances/partnerships or joint-developments (Grant and Baden-Fuller, 2004). Yet researchers argued that knowledge management should not be equated to implementing IT (Gold et al., 2001) and that knowledge management is much more than technology because individuals interacting within knowledge activities need social interaction - both for its own sake and because it provides a powerful vehicle for learning (Brown and Duguid, 2001; Hansen and von Oetinger, 2001). At the heart of knowledge management are fundamental changes in the ways organizations operate and people behave (Birkinshaw, 2001).

Communities of Practice (COP) theory addresses how individuals may create, mobilize and diffuse knowledge in a social setting. A COP is a self-organized group of employees 
who share common work practices, interests, or aims (Wenger, 2000). COP has illuminated (1) the understanding of how people interact that result the creation, mobilization and diffusion of knowledge, and (2) that COP and information technology are complementary as demonstrated by Hansen et al. (1999) in their study of strategies in managing knowledge.

Birkinshaw and Sheehan (2002) suggest a knowledge life-cycle theory where knowledge progresses through creation, mobilization, diffusion and commoditization stages. Furthermore, they argue that when implementing strategy for managing knowledge, an organization needs to understand the life-cycle of the knowledge in question, and the appropriate tools and techniques needed to generate value from knowledge in each knowledge life-cycle stage. Four categories are recommended for consideration in each: informal systems for mobilizing and sharing knowledge, information technology systems, human resources, and relationships with external parties.

\subsection{Discussion of literature}

While knowledge is understood as residing within individuals in an organization (Friedman, 2002; Nonaka and Takeuchi, 1995), we argue that the creation, mobilization, and exchange of the knowledge contextualized to an organization forms the basis for competitive advantage. We suggest that the purpose of knowledge management is not to manage all knowledge that exists within an organization. As McInnerney states, "Admitting that all (italics added) knowledge cannot be managed may help the credibility of knowledge management" (2002: 1013); moreover capturing all the targeted knowledge 
still remains unrealized (Hansen and Oetinger, 2001; Brown and Duguid, 2000). We consider knowledge management's objective is to optimize the management of that knowledge within an organization which can be turned into competitive advantage.

These conceptual inter-relationships are depicted in figure 1. The largest circle represents all knowledge within a particular organization. Within this is a subset of knowledge that can yield competitive advantage. The smallest circle represents this knowledge that is captured in the organization practice.

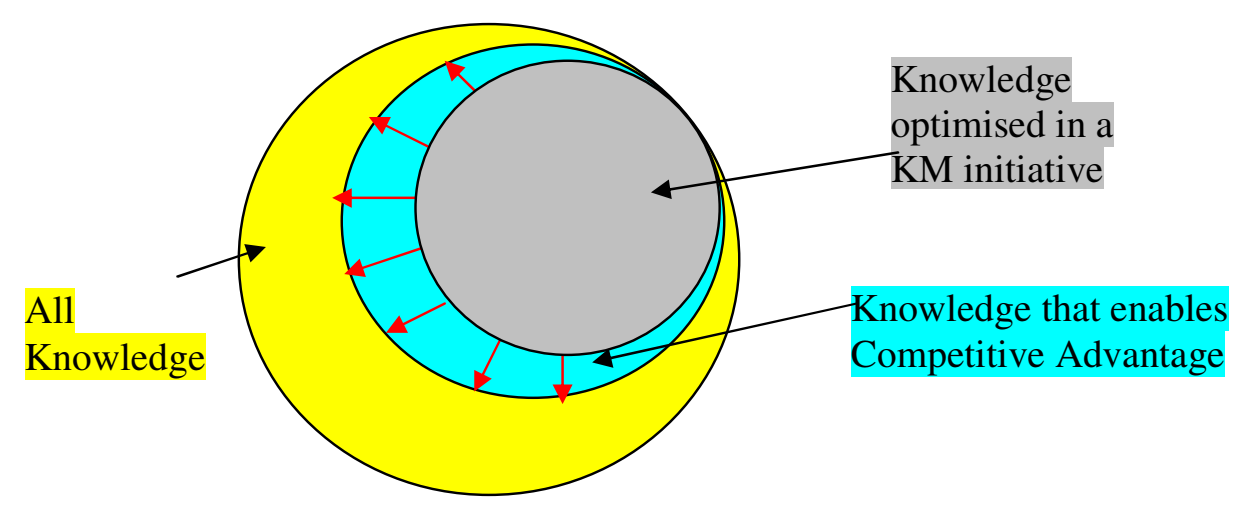

Figure 1. The conceptual inter-relationships of Knowledge, Knowledge that enables Competitive Advantage, and Knowledge captured in Knowledge Management.

The arrows from 'Knowledge optimized in a KM initiative' to 'Knowledge that enables Competitive Advantage' represent a knowledge management objective which is to expand knowledge that is translatable into competitive advantage.

Communities of practice that exchange complementary knowledge ought to have members that will want to enlarge the 'Knowledge optimized in a KM initiative' circle closer to the 'Knowledge that enables Competitive Advantage' (Wenger, 2000). Managing knowledge 
starts from its creation and follows through to its mobilization and exchange (Birkinshaw and Sheehan, 2002). Hence, organizations opting to use technology for knowledge management need to define what knowledge is going to be managed that can yield competitive advantage and how the creation, mobilization, and exchange of this knowledge is to be performed, the process, to facilitate COPs to enlarge the 'Knowledge optimized in a KM initiative' circle to ideally 'the knowledge that enables competitive advantage' circle.

The relationship between IT and Knowledge Management is problematic. IT offers three vital things: size, breadth and speed. Technology allows much greater volumes of knowledge to be accumulated, stored, manipulated and shared between a much greater number of people and move around in very much shorter periods of time than managing knowledge without technology. The impact of a global organization's IT systems shutting down for hours and days can be catastrophic. Yet, in spite of IT's importance, knowledge management relegates technology behind an organization's social, behavioral and cultural characteristics. Nonetheless, the temptation, therefore, to focus on the technology is both seductive and practical. Organizations make significant investments in technology to support knowledge management - according to Gilmour (2003) US organizations spent $\$ 4.5$ billion on knowledge-related software and technologies. This has three immediate implications. First, senior executives from IT and the business want to ensure they receive a return on their investment and put in place benefits plans and metrics to demonstrate this. Second, the methods used to implement IT are often incompatible with managing knowledge simply because many of these methodologies are aimed at the roll out of the system to meet time, cost and quality criteria. Three, senior executives and line managers hand-over IT implementation to the IT experts and technology consultants and lose 
interest in the implementation of knowledge. Each of these lessens the probability of organizations achieving the full value of knowledge management.

Knowledge management has gone through different stages from its emergence in the early 1990s with different levels of acceptance and success in the business world. While many studies show that few benefits have been gained from managing knowledge (Gilmour, 2003), some studies report successes in implementing knowledge management (Hauschild et al., 2001; Davenport and Prusak, 1998). In other words, knowledge management promises much, but often delivers very little. Much research has been devoted to knowledge management and there are no simple solutions to this challenge. Our paper aims at contributing to the implementation of knowledge management that brings beneficial results.

\section{Study methods}

The study methods were based on the ontological view that reality is subjective and socially constructed, and that epistemologically, knowledge can be derived from individuals' every day concepts and meanings. We used qualitative methods in this study by conducting semi-structured interviews. Based on the constructs from the data, an analysis was carried out to determine the findings.

This study was based on participant-observation principles where the observers share social world reciprocity with the interviewees (Singh and Dickson, 2002). The observers and interviewees are participants in interpreting the environment. This brings disadvantages and advantages. Advantages include the observers benefiting from having 
access to the interviewees for frequent dialogue and discussions, which lead observers to a deeper understanding of social processes, and that unspoken needs or demands can be discovered. The major disadvantage is observers' potential bias. This was overcome by using the techniques referred to as "mirroring" or "reflecting" (Easterby-Smith et al, 2002). This technique involves expressing in the researchers' own words what the respondent has just said. This may force the respondent to rethink his/her answer and reconstruct another reply that will amplify the previous answer. Practically, we use question statements such as: "What you seem to be saying is ...."

We used theoretical sampling to select specific cases for exploration (Eisenhardt, 1989). Two criteria guided our sample choice. One is an intranet-technology based system that supports decision-making that is knowledge intensive. The second is that it is operational knowledge management that has brought beneficial results.

We chose Gamma International because it met these two theoretical criteria. It has an intranet-technology based system, "CONNECT", that supports managers in making decisions to provide seamless operations to clients. It is also shown to have satisfied the users, demonstrated quantifiable benefits, and it has obtained recognition from the industry. This system operates in a technical service delivery process covering more than 100 countries, with 20 engineering centers, 5 research centers, multiple divisions, functions and products.

The semi-structured interviews were conducted around the questions to elaborate the benefits and the questions as to what actions Gamma International took in implementing their knowledge management system: CONNECI. 
For the study, 19 interviews carried out with Gamma International employees in their different roles related to CONNECT. The interviewees are 7 people from the CONNECT core team, 7 people from the CONNECT users, and 5 people from top management. Table 1 gives the list of the interviewees and their positions in the company.

Because the study covers an international use of CONNECT, geographical coverage is also ensured through the choice of the interviewees. As Gamma International is divided into three different geographical areas and one Headquarters, the areas where the interviewees come from are also expressed in the same way as Gamma International's use of geographical terminology. Note that the geographical areas do not represent the nationality of the interviewees but represent the geographical areas where they work. 4 people work in the North and South America area (NSA), 5 people work in the Europe, CIS, and Africa (ECA) area, 4 people work in the Middle East and Asia (MEA) area, and 6 people work in the headquarters (HQ).

All respondents were informed that the interview data and their identities would be kept confidential. Interviews with respondents in the USA, Australia and Japan were conducted by telephone. In 11 cases, conversations were also continued after the recorder was turned off. Any additional data or deviations from the recorded data were recorded in hand written notes. These data were used in subsequent data analysis. In one case, as requested by the respondent, a series of written questions was first sent to him and answered by him prior to the allocated interview time for the reason of 'focus' on the discussion during the interview. All interviews were recorded and transcribed. Constructs were then extracted from each interview. Emerging constructs were then identified and presented as the findings. 


\begin{tabular}{|c|c|c|c|c|}
\hline Name & Geographical Area & $\begin{array}{l}\text { Time of } \\
\text { interview }\end{array}$ & $\begin{array}{l}\text { Years } \\
\text { seniority }\end{array}$ & $\begin{array}{l}\text { Position related } \\
\text { CONNECT }\end{array}$ \\
\hline $\begin{array}{l}\mathrm{AK} \\
\text { (core) }\end{array}$ & $\begin{array}{l}\text { Paris, France } \\
\text { HQ }\end{array}$ & $\begin{array}{l}\text { Oct } 2003 \\
60 \text { minutes }\end{array}$ & 16 & $\begin{array}{l}\text { CONNECT Manager at } \\
\text { the engineering ctr. }\end{array}$ \\
\hline $\begin{array}{l}\mathrm{CM} \\
\text { (core) }\end{array}$ & $\begin{array}{l}\text { Houston, US, } \\
\text { NSA }\end{array}$ & $\begin{array}{l}\text { Oct \& Nov } \\
2003 \\
70 \text { minutes }\end{array}$ & 31 & $\begin{array}{l}\text { Technical Manager } \\
\text { D\&M Headquarters }\end{array}$ \\
\hline $\begin{array}{l}\mathrm{RH} \\
\text { (user) }\end{array}$ & Edinburgh, UK & $\begin{array}{l}\text { Oct } 2003 \\
45 \text { minutes }\end{array}$ & 06 & Field Engineer \\
\hline $\begin{array}{l}\text { YTL } \\
\text { (user) }\end{array}$ & $\begin{array}{l}\text { Kuala Lumpur, } \\
\text { MEA }\end{array}$ & $\begin{array}{l}\text { Dec } 2003 \\
30 \text { minutes }\end{array}$ & 07 & Field Engineer \\
\hline $\begin{array}{l}\text { AJ } \\
\text { (top) }\end{array}$ & $\begin{array}{l}\text { Kuala Lumpur, } \\
\text { MEA }\end{array}$ & $\begin{array}{l}\text { Dec } 2003 \\
21 \text { minutes }\end{array}$ & 20 & Product Champion \\
\hline $\begin{array}{l}\text { JD } \\
\text { (top) }\end{array}$ & $\begin{array}{l}\text { Paris, France } \\
\text { HQ }\end{array}$ & $\begin{array}{l}\text { Dec } 2003 \\
45 \text { minutes }\end{array}$ & 30 & Quality Director \\
\hline $\begin{array}{l}\text { GA } \\
\text { (top) }\end{array}$ & $\begin{array}{l}\text { Austin, US, } \\
\text { HQ }\end{array}$ & $\begin{array}{l}\text { Dec } 2003 \\
45 \text { minutes }\end{array}$ & 18 & IT Director \\
\hline $\begin{array}{l}\text { LPG } \\
\text { (core) }\end{array}$ & $\begin{array}{l}\text { Paris, France } \\
\text { ECA }\end{array}$ & $\begin{array}{l}\text { Dec } 2003 \\
90 \text { minutes }\end{array}$ & 15 & IT services \\
\hline $\begin{array}{l}\text { SB } \\
\text { (top) }\end{array}$ & $\begin{array}{l}\text { London, UK } \\
\text { HQ }\end{array}$ & $\begin{array}{l}\text { Dec } 2003 \\
30 \text { minutes }\end{array}$ & 21 & $\begin{array}{l}\text { President - } \\
\text { Business Unit }\end{array}$ \\
\hline $\begin{array}{l}\text { PD } \\
\text { (core) }\end{array}$ & $\begin{array}{l}\text { Paris, France } \\
\text { HQ }\end{array}$ & $\begin{array}{l}\text { Jan } 2004 \\
90 \text { minutes }\end{array}$ & 19 & $\begin{array}{l}\text { CONNECT Product } \\
\text { champion }\end{array}$ \\
\hline $\begin{array}{l}\mathrm{SC} \\
\text { (top) }\end{array}$ & $\begin{array}{l}\text { Paris, France } \\
\text { HQ }\end{array}$ & $\begin{array}{l}\text { Jan } 2004 \\
30 \text { minutes }\end{array}$ & 15 & Personnel Manager \\
\hline $\begin{array}{l}\text { HA } \\
\text { (user) }\end{array}$ & $\begin{array}{l}\text { Houston, US, } \\
\text { NSA }\end{array}$ & $\begin{array}{l}\text { Jan } 2004 \\
45 \text { minutes }\end{array}$ & 24 & Technical Manager \\
\hline $\begin{array}{l}\mathrm{TS} \\
\text { (core) }\end{array}$ & $\begin{array}{l}\text { Houston, US } \\
\text { NSA }\end{array}$ & $\begin{array}{l}\text { Jan } 2004 \\
60 \text { minutes } \\
\end{array}$ & 26 & $\begin{array}{l}\text { CONNECT Champion } \\
\text { NSA }\end{array}$ \\
\hline $\begin{array}{l}\text { JLP } \\
\text { (core) }\end{array}$ & $\begin{array}{l}\text { Houston, US } \\
\text { NSA }\end{array}$ & $\begin{array}{l}\text { Jan } 2004 \\
30 \text { minutes } \\
\end{array}$ & 30 & Technical Manager \\
\hline $\begin{array}{l}\text { MRK } \\
\text { (user) }\end{array}$ & $\begin{array}{l}\text { Clamart, France } \\
\text { ECA }\end{array}$ & $\begin{array}{l}\text { Jan } 2004 \\
45 \text { minutes }\end{array}$ & 7 & Field Engineer \\
\hline $\begin{array}{l}\begin{array}{l}\text { LP } \\
\text { (user) }\end{array} \\
\end{array}$ & $\begin{array}{l}\text { Clamart, France } \\
\text { ECA }\end{array}$ & $\begin{array}{l}\text { Jan } 2004 \\
45 \text { minutes } \\
\end{array}$ & 23 & CONNECT support \\
\hline $\begin{array}{l}\mathrm{KR} \\
\text { (core) }\end{array}$ & $\begin{array}{l}\text { Fuchinobe, Japan } \\
\text { MEA }\end{array}$ & $\begin{array}{l}\text { Jan } 2004 \\
45 \text { minutes }\end{array}$ & 31 & Technical Manager \\
\hline $\begin{array}{l}\text { AM } \\
\text { (user) }\end{array}$ & $\begin{array}{l}\text { Perth, Australia } \\
\text { MEA }\end{array}$ & $\begin{array}{l}\text { Feb } 2004 \\
45 \text { minutes }\end{array}$ & 7 & Field Engineer \\
\hline $\begin{array}{l}\text { BA } \\
\text { (user) }\end{array}$ & $\begin{array}{l}\text { Paris, France } \\
\text { ECA }\end{array}$ & $\begin{array}{l}\text { Feb } 2004 \\
30 \text { minutes }\end{array}$ & 19 & Document Manager \\
\hline
\end{tabular}

Table 1: List of interviewees for CONNECT case. 


\section{Findings}

\subsection{Industry and company environment}

The nature of the oil business involves high value assets that incur significant costs. Rapid and accurate decision-making is crucial. Therefore, managing knowledge in the oil sector becomes business-critical. Organizations serving the oil industry must, consequently, respond to this intensive requirement for shared knowledge. Therefore, the need to manage knowledge is arguably more acute in the oil sector than in other industry sectors.

Decision makers often need to integrate specialized and local knowledge. Two examples are technical knowledge about extracting a drill string, which can have a value of more than $\$ 200$ millions, stuck 1000 meters below the seabed, with local information from engineers on the platform who have to release the drill string. Another example is the exploration of a new oilfield and exploitation of producing fields; here, actions taken by field managers in, say, the Middle East will depend on decisions made by executives located in various American, Far Eastern or European cities. In turn, to effectively manage the global organization, Gamma International's executives need to be familiar with the actions taken in the field while exploration and exploitation work is underway.

Gamma International, a leading oilfield services company, must provide their clients - oil companies - with seamless operations and provide relevant knowledge at the right time. To transform its operations in technical service delivery, Gamma International created and implemented ConNECT to facilitate the creation, mobilization, and diffusion of knowledge 365 days a year, everywhere and at any time. In common with large global organizations, Gamma International has knowledge that is scattered across the world. Decision makers in any part of the structure often need to be able to integrate local knowledge with that which 
is held in some other part of the organization. This knowledge, embodied in a person or information encased in a data warehouse, could be in the office next door or on the other side of the globe.

\subsection{Creating, mobilizing, and exchanging knowledge prior to" CONNECT"}

Prior to CONNEET, the chain of knowledge and information flow can be presented as in figure 2. A delivery site manager needing specific knowledge was required to direct the request through the country and geographical area management. In turn, the geographical area management would communicate the request to the product line headquarters who then direct it to the product development manager in the relevant technology centre. Within this centre, the request would flow down to the subject matter expert. The reverse flow took place to transfer the knowledge required from the subject matter expert to the delivery site manager. The turn around time could be between two and sixteen weeks to answer a technical assistance request, sixteen weeks to resolve engineering modifications, and more than two years to update documentations.

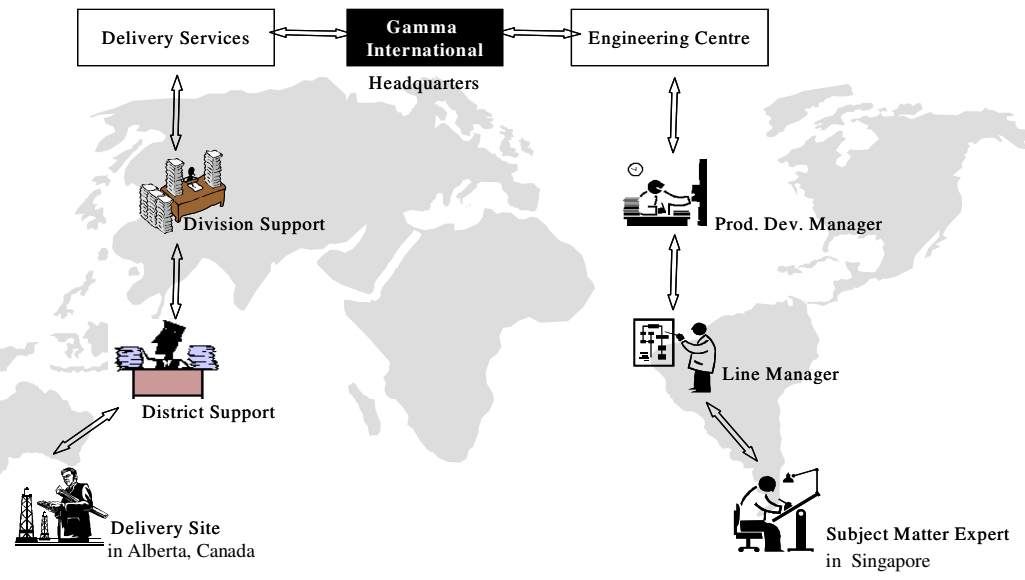

Figure 2. The chain of information and knowledge flow prior to CONNECT 


\subsection{Creating, mobilizing, and exchanging knowledge with" CONNECT"}

The main role of CONNECT is to link the field service delivery organization and the technology centers. CONNECT was designed and built internally within the organization's system and it forms a framework that facilitates knowledge management within the technical service delivery process. This is presented in Figure 3. The previous process is now disabled and replaced by the direct link system.

Delivery site managers looking for some answers or knowledge relevant to their needs inquire from CONNECT and seek the knowledge they require in real time. When the required knowledge is not found in the system, delivery site managers pose questions to the system.

"CONNECT support managers" located in different technology centers, act as knowledge brokers, providing the support promptly. They, being located in the technology centers, identity the relevant subject matter expert(s) almost immediately. Answers are recorded in the system and are made available to all users when the system is interrogated. When appropriate, answers may be 'validated' by other delivery site managers who are identified and volunteer themselves. Internally, they are referred to as "Applied Expert". This community of applied experts can also be the targeted experts of CONNECT support managers when posed questions are more application oriented. This describes the stage of knowledge creation and the mobilization of the validated knowledge. 


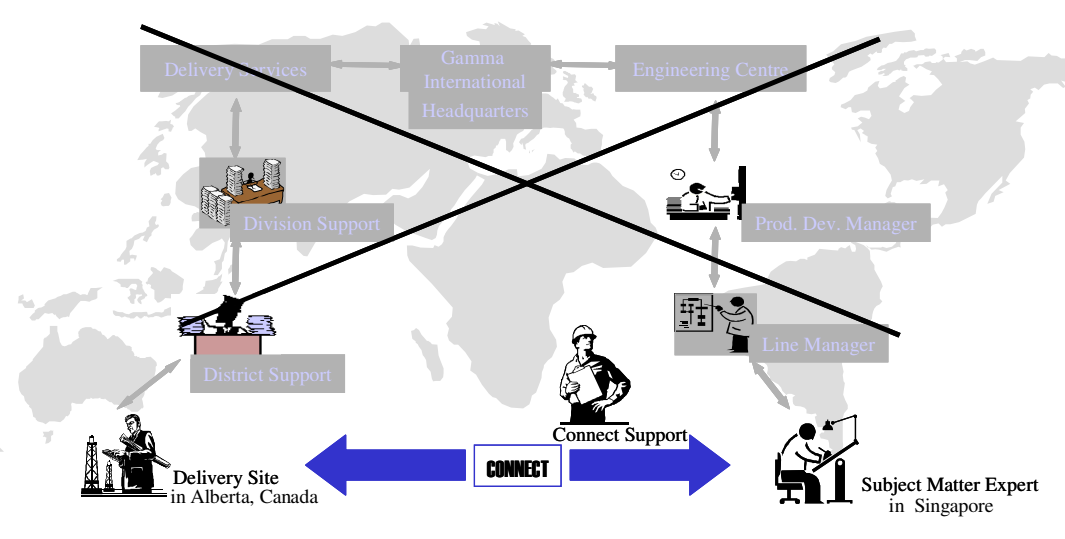

Figure 3. CONNECT links directly the field delivery site and the technology centres

When the knowledge sought from the system is found to be relevant, the delivery site managers take and reuse this knowledge for their needs. After reuse, they provide feedback and, when necessary, suggest improvement; thereby adding to CONNECT overall content. This describes the stage of knowledge exchange. Because the system contains the details and the recognition of contributors and it links to the corporate directory, direct people-to-people interaction is also facilitated.

Although the main purpose of the system is to support the technical service delivery process, it turns out that, with the captured knowledge and the intensive exchanges between different COPs, it has contributed to the integration of knowledge creation within the new product or service development in the research and engineering domain.

To enable delivery site managers and experts to use the system, each of them is equipped with a laptop computer loaded with standard software. The managers can search for validated information and best-practice, and share knowledge. The intranet-technology allows users to pose queries and receive answers 365 days a year regardless of global 
location.

\subsection{Metrics}

Measurements is a key component of Connett. Phase one was focused on the introduction to the delivery sites. It tracked the progress according to the plan in terms of expenses, percentage of targeted users trained and employees' awareness. Phase two concentrated on shared knowledge from the experts. The amount of shared content was then measured. Once the knowledge base had reached a critical mass, phase three then emphasized the reuse of others' knowledge by delivery site users. Measures, in addition to the amount of shared content, were put in place to acknowledge the quality of shared content, the reuse and improvement of others' contributions. Four different metrics were used:

Implementation. Measurements during the introduction were largely project management indices. These included associated costs and milestones reached regarding the application implementation.

Participation. An important gauge of the usefulness is the actual usage of the system. Several measurements were made automatically by the process, such as the number of unique delivery site users logging into the system daily, as well as previews of various content in the knowledge base.

Satisfaction. User surveys were conducted regularly whereby users provide input on changes that would improve their usage and efficiency.

Impact, The most difficult measurement is that of the impact of knowledge exchange on the business. Determining this impact was done using a feedback input on changes that would improve their usage and efficiency in performing their activities. 


\subsection{Benefits resulting from "CONNECT"}

\subsubsection{Competitive advantage}

By implementing CONNEEI, Gamma continues to differentiate itself through the creation and growth of its technological capabilities. Leonard-Barton (1998) insists that organizations who understand and develop the management of knowledge will dominate competitively, because products are physical manifestations of knowledge, and their worth largely, if not entirely, depends on the value of the knowledge they embody. An external survey shows that the system has generated cost savings and revenue totaling more than \$200 million, with a $95 \%$ reduction in the time required to solve operational-problems and a $75 \%$ decrease in the time necessary to update engineering modifications.

\subsubsection{Process within the new form of the organization is enabled}

In the past, e-mails and phone calls were the primary means for discussing technical issues in decision-making. This involved a multi-layered hierarchy. Since operationalizing CONNECT, the system captures knowledge requests, records validated answers and promotes best-practice. With all information flowing through a single communication channel, CONNECT, Gamma is able to apply the knowledge to provide seamless operations with solutions. This is achieved by capturing the knowledge of individuals, sharing it with others in the organization, keeping the knowledge flowing across functional boundaries, renewing knowledge, and providing a contextual environment within which to manage knowledge. CONNEGT provides the "space" (Nonaka and Konno, 1998) for the COPs. In fact, the previous organization's knowledge flow cannot be effectively sustained within the matrix organization. The delivery sites are now under the responsibility of the Regional organization and the technology centers are under the responsibility of the Business Lines. 
Therefore, providing the "space" for direct interaction ultimately solved the hierarchical issue. The intranet technology-based system has enabled the technical service delivery process to function with a common global standard.

\subsubsection{Improved speed and quality of technology solutions provided to clients}

With users actively creating, mobilizing, and exchanging knowledge across functional and regional boundaries, the system expands the capabilities of the technology centers to understand the needs of the delivery-based managers in a much shorter time. The result is that the technology centers can define issues more accurately and propose solutions which are more relevant and reliable, hence, the improved speed and quality of technology solutions provided to clients.

\subsubsection{Meritocracy of ideas}

Creation of new knowledge is often within knowledge exchange activities (Hargadon and Sutton, 2000; Nonaka I., 1991). Newly acquired knowledge interacts with existing knowledge to spark ideas. Hansen (2001), Wenger (2000), Nonaka and Takeuchi (1995) commend that the major source of new knowledge is bringing together people with different ideas to work on the same problem. Davenport and Prusak further emphasize that active knowledge interaction brings a meritocracy of ideas - it continually validates and refines knowledge, it tests official beliefs and exposes the flaws of the faulty ones, espouses the ones with merit. Operationalizing CONNECT has triggered open feedback and debate among delivery site managers, subject matter experts, and applied experts, to find better solutions for clients. 


\subsubsection{Job enrichment to employees}

Implementing CONNECT means changing roles for some people in Gamma. Positions related to the knowledge flow prior to the system were suppressed and new positions were created - from "pushing the knowledge flow" positions, to "finding solutions" ones. Drucker (1993; 1988) anticipated that the roles of knowledge workers would transform into knowledge intensive roles. Managing knowledge for decision-making to provide improved solutions real time seems to have enriched the jobs of some employees. With the extensive exchange within CONEET, horizontal integration of knowledge workers (Ghoshal and Gratton, 2002) appears to have helped users motivated to further share knowledge.

\subsubsection{Real time access to knowledge}

In the past, getting the required knowledge might have taken days or weeks. With CONNECT, users can access and interrogate the system at any time from anywhere. This, in turn, allows users to perform their activities with knowledge support real-time.

\subsubsection{Efficient link between delivery sites and technology centers}

CONNECT links the delivery sites and the technology centers. It connects directly the people who need knowledge in delivering service and business results to subject matter experts. As a result of CONNECT, a delivery site manager in offshore Indonesia or the Congo has the same level of knowledge support as a delivery site manager in West Texas or the North Sea, and they both benefit from each other's experiences and, when required, people to people collaboration can be facilitated through the system. 


\subsubsection{Quick response adjustment through use of metrics}

The creative use of information and metrics within the system allows Gamma to identify the business-critical issues and make quick-response adjustments to training courses, services specifications, or documentation in a swift manner.

\section{Discussion}

\section{Lesson 1: The scope of knowledge to be managed needs to be defined}

Drucker (1995) argues that managers must know what information and knowledge they need for them to make good decisions. Davenport and Prusak state, "What makes knowledge valuable to organizations is ultimately the ability to make better the decisions and actions taken on the basis of the knowledge" (1998:170). Therefore, as we argue in Figure 1 above, it is fundamental to define the scope of organizational knowledge to be managed that will improve decision-making. Gamma decided it was the operational and technology centre knowledge in its technical service delivery process that will create competitive advantage. CONNECI manages this knowledge.

\section{Lesson 2: Knowledge management needs to be within the process that coordinates}

\section{workers performing their activities}

El Sawy et al (2001) and Braganza and Möllenkramer (2000) argue that knowledge management is required to support business processes in a firm. Tuomi (1999) insists that a business process has to be recognized in designing knowledge management. By business process we mean the coordination and integration of activities performed in different functions to create outputs that are of value to one or more stakeholders (Braganza and 
Möllenkramer, 2002; Hammer, 2002). Expecting knowledge workers to peruse repositories of knowledge in their spare time, or to share their own knowledge at leisure, is unrealistic (Ghoshal and Gratton, 2002). If knowledge is to improve decision-making, and that action takes place within business process performance, we suggest that knowledge management has to blend with how employees work on daily activities. CONNECT users create, mobilize, and exchange knowledge within their day-to-day work in delivering services to clients.

\section{Lesson 3: Organisation require a knowledge management governance process.}

Grover and Davenport state that, "One of the reasons that knowledge is such a difficult concept is because this process is recursive, expanding, and often discontinuous" (2001:8). Many cycles of creation, mobilization, and exchange of knowledge are concurrently

occurring in businesses. The consequence of this is that knowledge within a designated system will become disorganized and unreliable. Gamma created the knowledge process that governs how the creation, mobilization, and exchange of knowledge is supported within the Community of Practice Gamma refer to as "CONNECT support managers". This facilitates the production of reliable knowledge.

\section{Lesson 4: Metrics are important for implementing knowledge management}

In general, scholars agree that the use of metrics ensures the implementation of a strategy or an idea (Kaplan and Norton, 2001; Drucker, 1986). Gamma manages CONNECT performance and its impacts through metrics. For example, to ensure the knowledge sharing activity, a metric measuring the number of contributions (shared knowledge) per employee is measured. Another example of metrics is the one that identifies current 
business-critical issues. The objective of these metrics is to ensure quick-response adjustment to those issues. Designing metrics in knowledge management is a matter that is not often mentioned in the literature. It seems, though, that Gamma International manages to react and provide the necessary actions to CONNECT users and clients by using the metrics built into it.

\section{Lesson 5: Knowledge based systems are critical to extend the reach and enhance the speed of knowledge exchange}

When organizations want to use knowledge in real-time, mission-critical applications they have to structure the knowledge base for rapid, precise access (Grover and Davenport, 2001). We contend that managers, not only need to know what knowledge they need for them to make good decisions, but must also know how to access the knowledge efficiently. Knowledge based systems makes it possible to exchange knowledge to a greater extent and at higher speed. Business leaders recognize that the use of knowledge affects their organization's competitive position (Braganza and Morgan, 2000). This is what Gamma has done in creating CONNECT as their knowledge-based system to mediate decision-making that brings advantages. CONNECT makes knowledge exchange become geographically borderless and makes knowledge available in real-time.

\section{Putting the horse before the cart}

Gamma International has benefited from intranet-technology because it focuses first on knowledge management aspects before embarking on the information technology tool. In other words, CONNECT puts the horse before the cart. Managing knowledge is much more than technology, and treating knowledge management as an IT-enabled program or project 
misses the point. Even the term knowledge based system is of concern because the focus of management attention becomes the 'system' rather than knowledge. Business and IT managers in organizations put in place targets, objectives and methods for choosing specific technologies (McAfee, 2003; Ross and Weill, 2002; Weill, 2002). We argue that this attention is misplaced; instead, like Gamma International, organizations need to make knowledge the focal point. Thus, the creation, mobilization and diffusion of knowledge across geographical and functional borders and to reduce time delay is where management ought to concentrate their energy.

\section{Summary}

We have explored how an oilfield services company uses an intranet-technology based system to create, mobilize, and diffuse knowledge within its technical service delivery process. A number of lessons learned have led to a conclusion that choosing and implementing technology must come after the management of knowledge has been considered. Managers need to take responsibility for selecting relevant knowledge and its sources, for understanding and implementing how knowledge is accessed and channeled, for ensuring an effective governance process for knowledge is in place, for reinforcing the importance and quality of knowledge through the use of metrics, and, ultimately, for putting knowledge management in front of technology.

Reference List

Barney, J.B. (1991), 'Firm Resources and Sustained Competitive Advantage', Journal of Management, Vol. 17 , No. 1, pp. 99-120.

Birkinshaw, J. (2001), 'Why Is Knowledge Management So Difficult?', Business Strategy Review, Vol. 12, No. 1, Spring, pp. 11-18. 
Birkinshaw, J. and Sheehan, T. (2002), 'Managing the Knowledge Life Cycle', MIT Sloan Management Review, Fall, pp. 75-83.

Blair, D.C. (2002), 'Knowledge Management: Hype, Hope, or Help?', Journal of the American Society for Information Science and Technology, Vol. 53(12), October, pp. 1019-1028.

Boisot, M. and Griffiths, D. (2001), 'To Own or to Possess? Competence and the Challenge of Appropriability', in Sanchez, R. (ed), Knowledge Management and Organizational Competence, Oxford Press, Oxford, pp. 210-226.

Braganza A. and Lambert, R. (2000), 'Strategic Integration: Developing a Process-Governance Framework', Knowledge and Process Management, Vol. 7, no. 3, pp. 177-186.

Braganza, A. and Morgan, C. (2000), 'Mature Organizations and the Internet: Lessons for Net-Competition', Int. J. Services Technology and Management, Vol. 1, No. 4, pp. 447-458.

Braganza, A. and Möllenkramer, G.J. (2002), 'Anatomy of a Failed Knowledge Management Initiative: Lessons From PharmaCorp's Experiences', Knowledge and Process Management, Vol. 9, no. 1, pp. 23-33.

Brown, J.S. and Duguid, P. (2000), 'Balancing Act: How to Capture Knowledge Without Killing It', Harvard Business Review, May-June, pp. 73-80.

Brown, J.S. and Duguid, P. (2001), 'Knowledge and Organization: A Social-Practice Perspective', Organization Science, Vol. 12, No. 2, pp. 198-213.

Buckley, P.J. and Carter, M.J. (2000), 'Knowledge Management in Global Technology Markets', Long Range Planning, Vol. 33, No. 1, pp. 55-71.

Cummings, J.N. (2004), ' Work Groups, Structural Diversity, and Knowledge Sharing in a Global Organization', Management Science, Vol. 50, No. 3, March, pp. 352-364.

Davenport, T. (1994), 'Saving IT's Soul: Human-Centered Information', in Harvard Business Review (ed), Harvard Business Review on the Business Value of IT, Harvard Business Review, Boston, pp. 1-33.

Davenport, T.H., de Long, D.W. and Beers, M.C. (1998), 'Successful Knowledge Management Projects', Sloan Management Review, Vol. 39, No. 2, pp. 43-57.

Davenport, T.H. and Prusak, L. (1998), Working Knowledge: How Organizations Manage What They Know, Harvard Business School Press, Boston.

Davenport, T.H., Prusak, L. and Wilson, H.J. (2003), What's the Big Idea?, Harvard Business School Press, Boston, USA.

Drucker, P.F. (1995), Managing in a Time of Great Change, Truman Talley Books/ Dutton, New York.

Drucker, P.F. (1986), The Practice of Management, HarperCollins, New York.

Drucker, P.F. (1988), 'The Coming of the New Organization', Harvard Business Review, January - February, pp. 98-111.

Drucker, P.F. (1993), Post-Capitalist Society, Butterworth Heinemann, Oxford.

Earl, M. and Scott, I. (1999), 'What Is a Chief Knowledge Officer?', Sloan Management Review, Vol. 40, No. 2, pp. 29-38.

Easterby-Smith, M., Thorpe, R. and Lowe, A. (2002), Management Research: An Introduction (2 edition), Sage, London. 
Eisenhardt, K.M. (1989), 'Building Theories From Case Study Research', Academy of Management Review, Vol. 14, No. 4, pp. 532-550.

El Sawy, O., Eriksson, I., Raven, A. and Carlson, S. (2001), 'Understanding Shared Knowledge Creation Spaces Around Business Processes: Precursors to Process Innovation Implementation', Int. J. Technology Management, Vol. 22, no. 1/2/3, pp. 149-173.

Francis, D. and Bessant, J. (2005), 'Targeting Innovation and Implications for Capability Development', Techovation, Vol. 25, pp. 171-183.

Friedman, V.J. (2002), 'The Individual As Agent of Organizational Learning', California Management Review, Vol. 44, No. 2, Winter, pp. 70-89.

Gilmour, D. (2003), 'How to Fix Knowledge Management', Harvard Business Review, Vol. 81, October, pp. 16-17.

Gold, A.H., Malhotra, A. and Segars, A.H. (2001), 'Knowledge Management: An Organization Capabilities Perspective', Journal of Management Information Systems, Vol. 18, No. 1, pp. 185-214.

Ghoshal, S. and Gratton, L. (2002), 'Integrating The Enterprise', MIT Sloan Management Review, Vol. 44, No. 1, Fall, pp. 31-38.

Grant, R.M. (1996), 'Toward a Knowledge-Based Theory of the Firm', Strategic Management Journal, Vol. 17, Winter special issue , pp. 109-122.

Grant, R.M. and Baden-Fuller, C. (2004), 'A Knowledge Accessing Theory of Strategic Alliances', Journal of Management Studies, Vol. 41, No. 1, January, pp. 61-84.

Grover, V. and Davenport, T. (2001), 'General Perspectives on Knowledge Management: Fostering a Research Agenda', Journal of Management Information Systems, Vol. 18, No.1, Summer, pp. 3-21.

Hammer, M. (2002), 'Process Management and the Future of Six Sigma', MIT Sloan Management Review, Winter, pp. 26-32.

Hansen, M.T., Nohria, N. and Tierney, T. (1999), 'What's Your Strategy for Managing Knowledge?', Harvard Business Review, March-April, pp. 106-116.

Hansen, M.T. and Oetinger, B.v. (2001), 'Introducing T-Shaped Managers: Knowledge Management's Next Generation', Harvard Business Review, March , pp. 106-116.

Hargadon, A. and Sutton, R.I. (2000), 'Building Innovation Factory', Harvard Business Review, May-June, pp. 157-166.

Hauschild, S., Licht, T. and Stein, W. (2001), 'Creating a Knowledge Culture', The McKinsey Quarterly, Vol. 1, pp. 74-81.

Kaplan, R.S. and Norton, D.P. (2001), The Strategy-Focused Organization: How Balanced Scorecard Companies Thrive in the New Business Environment, Harvard Business School Publishing, USA.

Kogut, B. (2000), 'The Network As Knowledge: Generative Rules and the Emergence of Structure', Strategic Management Journal, Vol. 21, pp. 405-425.

Kogut, B. and Zander, U. (1992), 'Knowledge of the Firm, Combinative Capabilities, and the Replication of Technology', Organizational Science, Vol. 3 no.3, August, pp. 383-397.

Leonard-Barton, D. (1998), Wellsprings of Knowledge: Building and Sustaining the Sources of Innovation (paperback edition), Harvard Business School Press, Boston, USA. 
McInerney, C. (2002), 'Knowledge Management and the Dynamic Nature of Knowledge', Journal of the American Society for Information Science and Technology, Vol. 53 (12), October, pp. 1009-1018.

Nonaka I. (1991), 'The Knowledge-Creating Company', Harvard Business Review, November-December, pp. 96-104.

Nonaka, I. and Takeuchi, H. (1995), The Knowledge Creating Company, Oxford University Press, Oxford.

Nonaka, I. and Konno, N. (1998), 'The Concept of "Ba": Building a Foundation for Knowledge Creation', California Management Review, Vol. 40 no.3, spring, pp. 40-54.

Ross, J.W. and Weill, P. (2002), 'Six IT Decisions Your IT People Shouldn't Make', Harvard Business Review, November, pp. 84-91.

Singh, V. and Dickson, J. (2002), 'Ethnographic Approaches of Organizations', in Partington, D. (ed), Essential Skills for Management Research, Sage Publishing, London, pp. 117-135.

Southon, F.C.G., Todd, R.J. and Seneque, M. (2002), 'Knowledge Management in Three Organizations: An Exploratory Study', Journal of the American Society for Information Science and Technology, Vol. 12 no.53, October, pp. 1047-1059.

Tuomi, I. (1999), 'Data Is More Than Knowledge: Implications of the Reversed Knowledge Hierarchy for Knowledge Management and Organizational Memory', Journal of Management Information Systems, Vol. 16, No. 3, pp. 103-117.

Weill, P.S.M.B.M. (2002), 'Building IT Infrastructure for Strategic Agility', MIT Sloan Management Review, Vol. 44, No. 1, Fall, pp. 57-65.

Wenger, E. (2000), 'Communities of Practice and Social Learning Systems', Organization, Vol. 7, No. 2, pp. 225-246. 